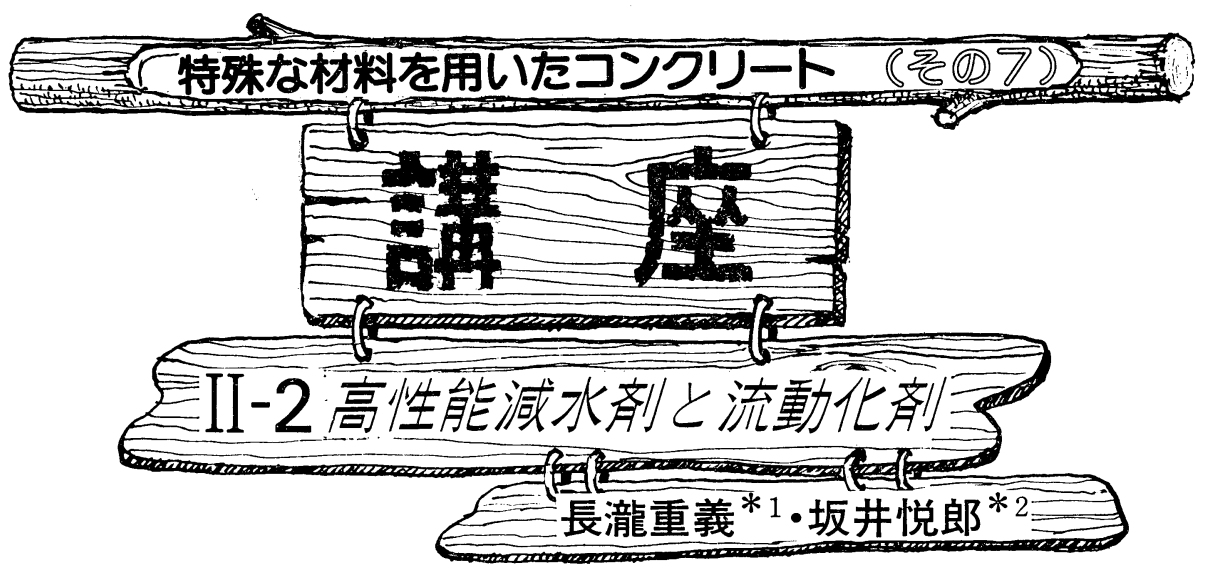

1.はじめに

減水性能が従来の減水郕より優れている，いわゆる高 性能減水剤を用いた高強度および流動化コンクリートの 使用が種々検討され，この種のコンクリートが，コンク リート分野で独自の地位を占めつつある。

我が国においては, 単位水量を減じ, 高強度を得るこ とを目的として，オートクレーブおよび蒸気養生高強度 ぐいやプレキャストコンクリートなどに高性能減水剤を 利用したのが始まりであり，コンクリートの高強度化の ためには必要不可欠な混和剂と考えられるようになって いる。また，この種のコンクリートを対象とした「高強 度コンクリート設計施工指針 (案)」も，土木学会より 昭和 55 年に刊行されている

一方, 流動性を向上させ，施工性を改善させるために 高性能減水剈を用いた，いわゆる流動化コンクリートは 西独においてその使用が開始されたが，我が国において もその利用が搪大しつつあり, 土木・建築両学会におい て「流動化コンクリート施工指針 (案)」も刊行されて (るる2,3)。

従って, 高性能減水剤や流動化剂に関しては, そ机ら を利用したコンクリートの性質も含めて多くの技術者に 理解されつつあるように思われるが，土木・建築の分野 においても, 高性能減水剤や流動化剂などにさらに詳細 な理解が必要と思われる。

ここでは, 高性能減水剤と流動化剂に関して, その作 用機構などを中心に, それらを用いたコンクリートの基 本的性質や応用例などの概略を説明する。

2. 高性能減水剤と流動化剂の種類

高性能減水剤と流動化剂は，その使用目的により区別

*1 正会員 東京工業大学教授 工学部土木工学科

$* 2$ 電気化学工業 (株) 中央研究所
されているものと理解すべきであろう。ACI 212 委員 会は，その報告に拉いて，“High-range water reducing admixture (Superplasticizer)”には，その使用目的と して次の 3 種類があることを述べている4)。

1）コンシステンシーを損なうことなく，また凝結時 間に好ましくない影響を与えることなく，モルタ ル,コンクリートの単位水量を大幅に減少させるた めに使用する。

2）元の配合の単位水量を増加させることなく，スラ ンプを著しく増大させるために使用する。

3）1）および 2) を併せた目的に使用するものであ り, 中程度の減水とスランプを増加させるために用 いる。

上記, $\mathrm{ACI}$ の分類における 1) の目的のために使用す るものが高性能減水剂，2）の目的に用いるものが流動 化剤であるということができる。

表一1 コンクリート流動化剤品質規準

\begin{tabular}{|c|c|c|c|c|}
\hline \multicolumn{3}{|c|}{ 項 目 } & 標準 形 & 遲 延 形 \\
\hline 試 & スランプ $(\mathrm{cm})$ & $\begin{array}{l}\text { ベースコンクリート } \\
\text { 流動化コンクリート }\end{array}$ & \multicolumn{2}{|c|}{$\begin{array}{r}8 \pm 1 \\
18 \pm 1\end{array}$} \\
\hline $\begin{array}{l}\text { 条 } \\
\text { 件 }\end{array}$ & 空気量 (\%) & $\begin{array}{l}\text { ベースコンクリート } \\
\text { 流動化コンクリート }\end{array}$ & \multicolumn{2}{|c|}{$\begin{array}{l}4.5 \pm 0.5 \\
4.5 \pm 0.5\end{array}$} \\
\hline \multicolumn{3}{|c|}{ ブリージング量の差 $\left(\mathrm{cm}^{3} / \mathrm{cm}^{2}\right)$} & 0.1 以下 & 0.2 以下 \\
\hline \multicolumn{2}{|c|}{$\begin{array}{c}\text { 凝 結 時 間 の 差 } \\
\text { (min) }\end{array}$} & $\begin{array}{l}\text { 始 } \\
\text { 終 }\end{array}$ & $\begin{array}{l}-30 \sim+90 \\
-30 \sim+90\end{array}$ & $\begin{array}{l}+60 \sim+210 \\
+210 \text { 以下 }\end{array}$ \\
\hline \multicolumn{2}{|c|}{$\begin{array}{l}\text { スランプの経時 (15 分間) } \\
\text { 空気量の経時 (15 分間) }\end{array}$} & $\begin{array}{l}\text { 低下量 }(\mathrm{cm}) \\
\text { 低下量 }(\%)\end{array}$ & $\begin{array}{l}4.0 \text { 以下 } \\
1.0 \text { 以下 }\end{array}$ & $\begin{array}{l}4.0 \text { 以下 } \\
1.0 \text { 以下 }\end{array}$ \\
\hline \multicolumn{2}{|c|}{ 王縮強度比* $(\%)$} & $\begin{array}{llll}\text { 材 } & \text { 令 } & 3 & \text { 日 } \\
\text { 材 } & \text { 令 } & 7 & \text { 日 } \\
\text { 材 } & \text { 令 } & 28 & \text { 日 }\end{array}$ & $\begin{array}{l}90 \text { 以上 } \\
90 \text { 以上 } \\
90 \text { 以上 }\end{array}$ & $\begin{array}{l}90 \text { 以上 } \\
90 \text { 以上 } \\
90 \text { 以上 }\end{array}$ \\
\hline \multicolumn{3}{|c|}{ 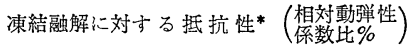 } & $\begin{array}{l}120 \text { 以下 } \\
90 \text { 以上 }\end{array}$ & $\begin{array}{l}120 \text { 以下 } \\
90 \text { 以上 }\end{array}$ \\
\hline
\end{tabular}

*この值は, 通常の試験誤差を考慮して定めたものであって, 流動化コ ンクリートがベースコンクリートと同等の品質を有すべきことを意味 する。 
表一2 市販流動化剂の標準添加量

\begin{tabular}{|c|c|c|c|c|}
\hline 型 & 商＼cjkstart品 & 成 & 添加量* $(\%)$ & 製造 (販売) 会社 \\
\hline \multirow{3}{*}{ 標 } & NP-10 & ナフタリンスルホン酸塩系複合物 & 0.06 & $\begin{array}{l}\text { 日曹マスタービルダーズ } \\
\text { ポソリ物産 }\end{array}$ \\
\hline & NP-20 & メラミンスルホン酸塩系袙合物 & 0.12 & $\begin{array}{l}\text { 日曹マスタービルダーズ } \\
\text { ポソス物産 }\end{array}$ \\
\hline & マイテイ FD & ナフタリンスルホン酸ホルマリン高縮合物 & 0.06 & 花王石嚧 \\
\hline \multirow[t]{2}{*}{ 準 } & ハイフルード & アルキルナフタリンスルホン酸塩縮合物 & 0.06 & 竹本油脂 \\
\hline & パリック FL & ナフタリンスルホン酸塩系縮合物 & 0.06 & 藤沢薬品工業 \\
\hline \multirow[t]{2}{*}{ 型 } & サンフロー FB & $\begin{array}{l}\text { ナフタリンスルホン酸・リグニンスルホン酸共縮 } \\
\text { 合物 }\end{array}$ & 0.06 & $\begin{array}{l}\text { 山陽国策パルプ } \\
\text { サンー }\end{array}$ \\
\hline & FT- 80 & $\begin{array}{l}\text { アルキルアリルスルホン酸塩および高性能リグニ } \\
\text { ンスルホン酸塩 }\end{array}$ & 0.08 & 電気化学工業 \\
\hline 遅 & NP-20 R & $\begin{array}{l}\text { メラミンスルホン酸塩系縮合物およびボリオール } \\
\text { 複合体 }\end{array}$ & 0.12 & $\begin{array}{l}\text { 日曹マスタービール゙ルダーズ } \\
\text { ポリス物 }\end{array}$ \\
\hline $3 F$ & マイティ FDR & ナフタリンスルホン酸ホルマリン高縮合物変性品 & 0.04 & 花王石喃 \\
\hline 建 & ハイフルードR & アルキルナフタリンスルホン酸塩縮合物 & 0.06 & 竹本油脂 \\
\hline 型 & サンフロー FBF & $\begin{array}{l}\text { ナフタリンスルホン酸・リグニンスルホン酸共縮 } \\
\text { 合物および特殊リリ゙ニンスルホン酸脬導体 }\end{array}$ & 0.12 & $\begin{array}{l}\text { 山陽国策パルプ } \\
\text { サンフ }\end{array}$ \\
\hline
\end{tabular}

* スランプ $1 \mathrm{~cm}$ 增大するのに必要なセメントの重量に対する標準添加量。配合，温度等により，この標準添加量は変化する。

これらの主成分は, 英国 CAA と CCA の報告 ${ }^{51}$ 亿打 いては, ナフタリンスルホン酸塩縮合物, メラミン樹脂 スルホン酸塩, 変性リグニンスルホン酸塩, およびカル ボン酸塩などのその他に分類されている。

我が国においては，高性能減水剤としてはナフタリン スルホン酸塩縮合物およびメラミン樹脂スルホン酸塩を 主成分とするものが市販されている。流動化剂もこれら を主成分とするものであるが, 空気量の安定や遅延性な どを付与したものが市販されている。

一般に高性能減水剂愉水作用が大きく, 凝結遅延や 空気連行などの悪影響が極めて小さいため添加量を増加 させることができ，25〜30\% の減水が可能であるとさ れている。しかしながら，これに関する品質規準はまだ 規格化されていない。一方, 流動化剂は土木・建築両学 会で統一された品質規準が 表一1 に示すごとく規定され ている ${ }^{2), 3)}$ 。表一2 に市販流動化剂の一例として, その 主成分, 標準的添加量を示した ${ }^{3)}$ 。

\section{3. 高性能減水剂と流動化剂の作用機構}

高性能減水剂と流動化剂の主成分をなすナフタリンス ルホン酸塩縮合物を中心に，その作用機構について考え てみよう。

まず, 図一1 は各種有機化合物を添加した際のセメン トペーストの見掛け粘度の変化を示したものである ${ }^{6)}$ 。 ポリビニルアルコールは, その添加量とともに粘度を増 加させるのに対し, リグニンスルホン酸塩やナフタリン スルホン酸塩縮合物は添加量の増加によりセメントペー ストの粘度を低下させる。ポリビニルアルコールは, 粒 子の橋かけによりセメントペーストの粘度を増加させる と考光られている。一方, ナフタリンスルホン酸塩縮合 物やリグニンスルホン酸塩の添加によるセメントペース トの粘度の低下（流動性の向上）はセメント粒子の分散 性と関連しているが，この点に関してさらに詳細に述べ

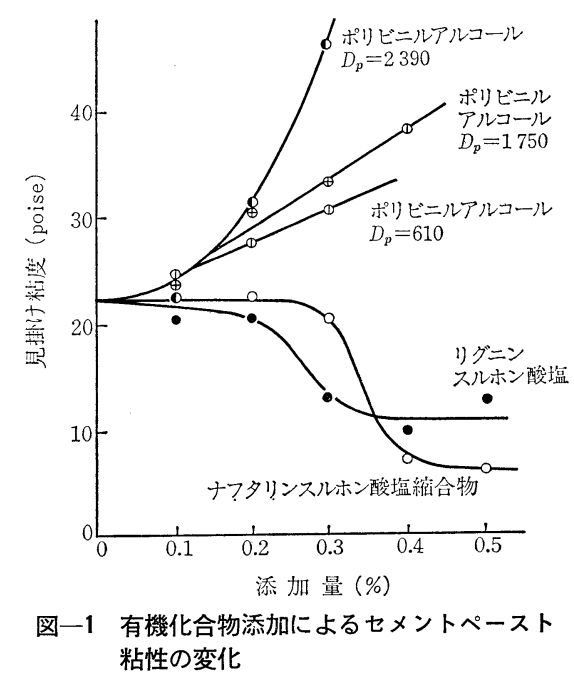

ることとする。なお, セメントの水和反応に対する遅延 作用はリグニンスルホン酸塩に比べてナフタリンスルホ ン酸塩縮合物で注著しく小さく, それ故, 多量に添加す ることが可能である。

粒子の分散性と関連しては, 隣接する带電した 2 粒子 間に働く静電的な反発力と London-van der Waals 引 カから考察することができる゙。これらは DerjaguinLandan のソ連グループと Verwey-Overbeek のオラン ダグループがそれぞれ独自に研究を進めていたもので, $\mathrm{D}-\mathrm{L}-\mathrm{V}-\mathrm{O}$ 理論といら。ここで静電的反発力とは, 電解 質を含む媒質中の帯電粒子間に存在するイオンの 2 重層 形成による反発力のことである。液中では, 粒子が電荷 をもつと, その反対符号のイオン (対イオン) が同量必 ず液中に存在し，この対イオンが带電した粒子の周囲に 引き寄せられて群っている。この様子を模式的に表した ものが 図一2(a) であり, この状態を電気 2 重層を形成 しているという。粒子同志が接近すると外側の対イオン 同志がぶつかりあい, その結果として電気的反発力が生 


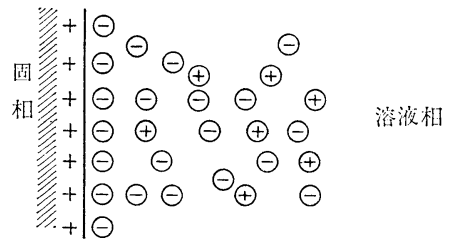

(a)

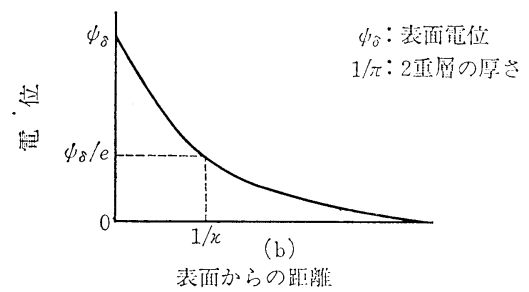

図一2 拡散 2 重層モデル

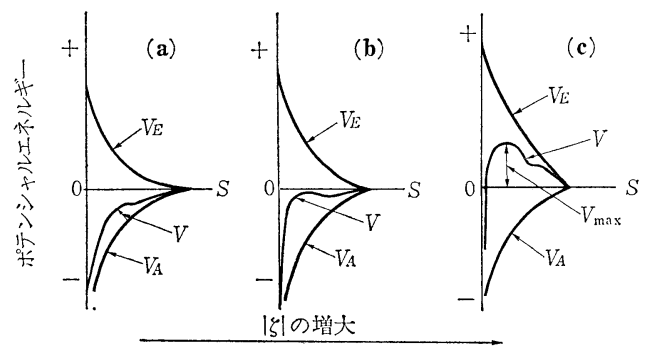

図一3 2 粒子間の相互作用ポテンシャル曲線

ずることとなる。通常, 対イオンは拡散的な分布をする ため, 図一2(b) に示すごとく表面の電位は表面から距 離とともに徐々に減少する。従って，電位がある特定な 值になる距離をもって 2 重層の厚さと呼んでいる。この ような電気 2 重層を粒子表面近傍で形成させ，粒子間に 働く引力 (London-van der Waals 力) に打ち勝っこと で，粒子は凝集することなく安定な分散状態を保つこと となる。このことは，2粒子間に働く力をポテンシャル エネルギーとして表し, 引力と斥力 (反発力) の和であ る相互作用ポテンシャル曲線から明らかとなる。図一3 に示すごとく ${ }^{8)}$, 電気的反発力の増大により 2 粒子間に 障壁が生じ，粒子は，それ以上近ゔくことができず，粒 子の凝集が防止され，この障壁が大きいほど粒子の分散 状態が維持されることとなる。

高性能減水剤や流動化剂の主成分であるナフタリンス ルホン酸塩縮合物は, セメント粒子に吸着して電気的な 反発力を増大させ，セメント粒子の分散状態を維持する 役目をすると考えることができる。このことは，ナフタ リンスルホン酸塩縮合物の添加によりセメント粒子が大 きな負電荷をもつようになることが多くの研究者により 実証されていることからも明らかである。図一1 に示し
たポリビニルアルコールの増粘作用と, ナフタリンスル ホン酸塩縮合物の分散作用を模式的に描くと図一4のよ うになる。

以上のごとく, 高性能減水剤や流動化剤のセメントペ 一ストの流動性の改善について, 分散系の安定性に関す る $\mathrm{D}-\mathrm{L}-\mathrm{V}-\mathrm{O}$ 理論に基づいて定性的に説明した。なお， セメント粒子が水和反応をするため通常この理論が適用 される疎水コロイドと若干異なった挙動を示すことも実 用上重要であり，理解する必要がある。ナフタリンスル ホン酸塩縮合物をセメント粒子が水と接触した後添加す ると, 通常の同時に添加する方法に比べて低い添加量で 流動性が改善される。このことは, リグニンスルホン酸 塩の遅延作用に扔いて最初発見されたものであるが9， 吸着量が少ないにもかかわらず, 後添加の方が大きな負 の表面電位を示すことによる ${ }^{10)}$ このことは，通常の添 加方法では注水直後にセメント鉱物中のアルミネート相 とナフタリンスルホン酸塩縮合物が反応し ${ }^{11)}$, 添加した ものが必ずしも有効に表面に吸着していないが, 後添加 では多くのナフタリンスルホン酸塩縮合物がセメント粒 子表面に有効仅着し, 分散作用に関与するものと考え ることができる。それ故, 後添加の方が少量のナフタリ ンスルホン酸塩縮合物の添加で, ペーストの流動性を改

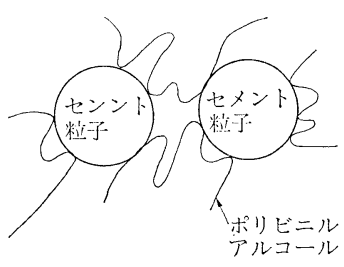

(a) 橋かけによる凝集作用 (ポリピニルアルコール)

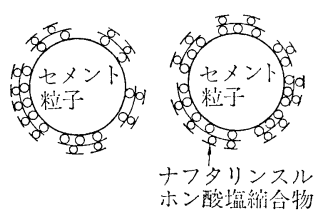

(b) 電気的反発力による分政作用 (ナフタリンスルホン酸塩維合物)

\section{図一4 有機化合物の吸着による各種作用の模式図}

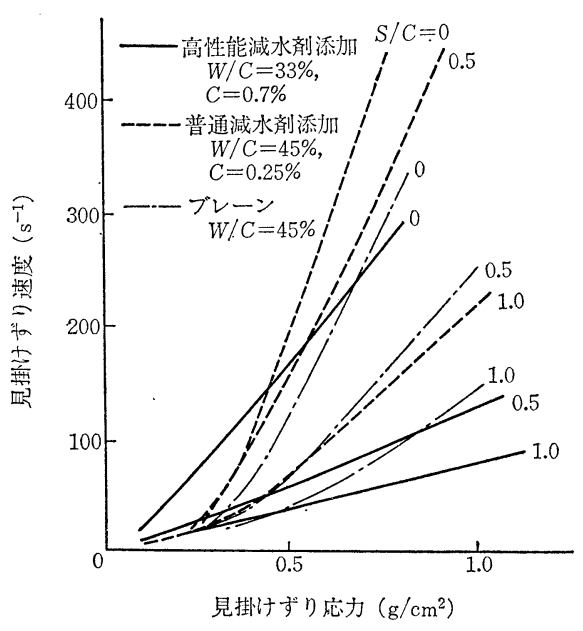

図一5＼cjkstart管式粘度計による流動特性 
善することができる。

なお，ペーストの流動性に関して，ナフタリンスルホ ン酸塩縮合物の添加により流動性を改善した場合にはレ オロジー的挙動が異なることも理解する必要がある。そ の一例を図一5に示したが12)，ビンガム流体からニュー トン流体に近づく。このため，ナフタリンスルホン酸塩 縮合物を添加した場合, 添加量の増加に伴うペーストの 塑性粘度の減少より降伏值の減少の方が大きい傾向を示 すとされている(13)。以上のことより，高性能減水剤を多 量に添加し練りまぜ水量を減少させた注入モルタルや高 強度コンクリートのフレッシュな状態は, 通常のものと 若干異なる傾向を示すこととなる。

\section{4. 高強度コンクリート}

高性能減水剤を添加し, 流動性を損なうことなく単位 水量を減少させることにより，水セメント比を低下さ せ，コンクリートを高強度化することが可能である。オ ートクレーブ養生あるいは蒸気養生と高強度混和材の併 用により $800 \mathrm{kgf} / \mathrm{cm}^{2}$ 以上のコンクリートが得られてお り, 高強度のプレストレストコンクリート（P C ) ぐい として実用されている。また, 場所打ち高強度コンクリ 一トの適用も検討され, 橋りょら ${ }^{14)}$, 橋脚, さらには流 動特性もすぐれていることから，高強度プレパックドコ ンクリートへの応用も検討されている ${ }^{15)}$ 。また, 高性能 減水剤とシリカ質微粒子と特殊な 骨材を組み合わせる ことにより，流動性のすぐれた，かつ圧縮強度が 2000 $\mathrm{kgf} / \mathrm{cm}^{2}$ 程度のコンクリートも出現してお ${ }^{16)}$, 今後の 高性能減水剤の広範な利用が期待される。

ここでは，一般的な高性能減水剤を用いた高強度コン クリートの諸性質や注意事項について述べる。

高性能減水剂を用いた高強度コンクリートの配合の一 例を表一3 に示した1)。このような配合であることか ら，高性能減水剤を用いた高強度コンクリートでは，使 用上, 品質管理上次のような点に注意する必要がある。

1）コンクリートの単位水量によるスランプの変動が 大きい。それ故，骨材の含水量等の管理が重要とな
る。また，骨材の粒度も影響する。

2）コンクリートのスランプロスが比較的大きい。

2）減水効果は，七メントの種類や品質，骨材の品 質, 細骨材率により異なる。また, 練上り温度も影 響を及ぼし, 温度の高いほど減水効果は良くなる が，スランプロスは逆の傾向を示す。従って，練上 り温度の適切な管理が必要となる。

高強度コンクリートの圧縮強度は, 図一6に示すごと くセメント水比に依存するが17)，800 1000 kgf $/ \mathrm{cm}^{2}$ の 圧縮強度がオートクレーブ養生と高性能減水剤の併用に より得られることが明らかとなっている。曲げ強度は圧 縮強度の $1 / 10$ 程度であり, 引張強度は圧縮強度の $1 / 16$ 程度となる。なお, 通常のコンクリートに比べ骨材の性 状が強度発現を大きく左右することに 注意が必要であ る。一般に, 硬質砂岩系のような組織が密で, 強度や弾 性係数が大きいものを選定してやるのが好ましい。骨材 の影響の一例を図一7 に示す ${ }^{18)}$ 。

$800 \sim 1000 \mathrm{kgf} / \mathrm{cm}^{2}$ の圧縮強度を示すコンクリートの 弾性係数注約 $4.0 \sim 4.5 \times 10^{5} \mathrm{~kg} / \mathrm{cm}^{2}$ 程度であり，また， 応力ーひずみ曲線においては, 強度の増加により弾性域 が大きくなるが, 塑性ひずみが小さくなっている。圧縮 強度の 小さいコンクリートの極限ひずみは $0.5 \%$ 程度

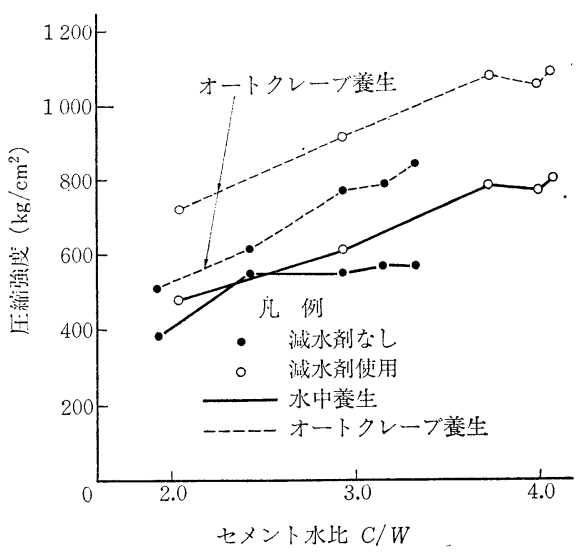

図一6高強度コンクリートのセメント水比と圧縮強度

表一3 高強度コンクリートの配合例

\begin{tabular}{|c|c|c|c|c|c|c|c|c|}
\hline 造 & $\begin{array}{c}\text { 設計基準強度 } \\
\left(\mathrm{kgf} / \mathrm{cm}^{2}\right)\end{array}$ & $\begin{array}{l}G_{\max } \\
(\mathrm{mm})\end{array}$ & $\begin{array}{l}\text { スランプ } \\
(\mathrm{cm})\end{array}$ & $\begin{array}{l}W / C \\
(\%)\end{array}$ & $\begin{array}{l}s / a \\
(\%)\end{array}$ & $\begin{array}{l}\text { 単 } \\
\text { セメント位 } \\
\left(\mathrm{kg} / \mathrm{m}^{3}\right)^{-9}\end{array}$ & $\begin{array}{l}\text { 高性能 } \\
\text { 滅剂 } \\
(\boldsymbol{C} \times \%)\end{array}$ & 工 \\
\hline $\begin{array}{l}\text { 場 所打 } \\
\text { プレスト } \\
\text { コンクリートト 形げた }\end{array}$ & 800 & 20 & $12 \pm 2.5$ & 30 & 40 & 484 & 0.75 & $\begin{array}{l}\text { 山陽新幹線 } \\
\text { 第二綾維本川橋梁 }\end{array}$ \\
\hline $\begin{array}{l}\text { プレストレスト } \\
\text { コンクリートラス }\end{array}$ & 800 & 20 & $12 \pm 2$ & 23 & 38.5 & 600 & 1.5 & $\begin{array}{l}\text { 山陽新幹線 } \\
\text { 岩罳架道橋 }\end{array}$ \\
\hline $\begin{array}{l}\text { プレストレスト* } \\
\text { コンクリートトラス }\end{array}$ & 800 & 20 & $12 \pm 2.5$ & 30 & 39.5 & 530 & 1.5 & $\begin{array}{l}\text { 久磁線 } \\
\text { 安家川橋梁 }\end{array}$ \\
\hline $\begin{array}{l}\text { プレストレスト** } \\
\text { コンクリートぐい }\end{array}$ & 800 & 30 & $8 \sim 12$ & $29 \sim 32$ & $41 \sim 42$ & $430 \sim 460$ & 1.2 & \\
\hline
\end{tabular}

*オートクレープ養生

**オートクレーブ養生か高強度混和秋と蒸気養生の併用

Vol. 24, No. 4, April 1986 


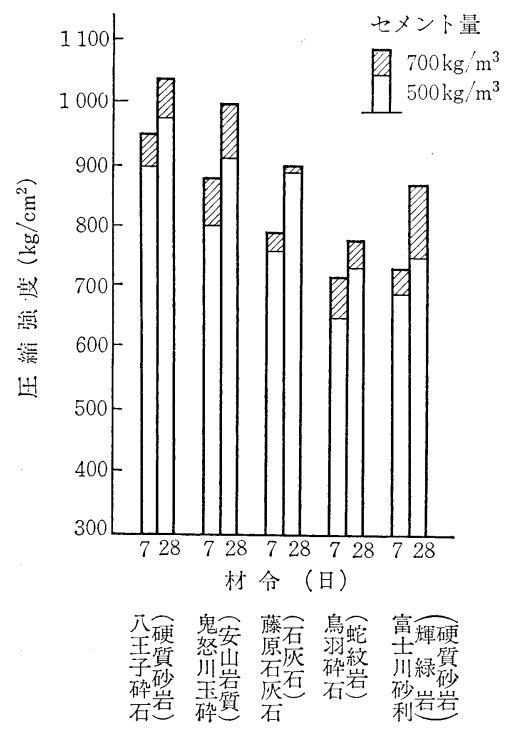

図一7圧縮強度に及ぼす骨材の影響

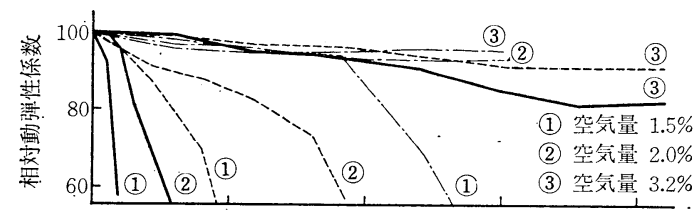

単位セメント量: $450 \mathrm{~kg} / \mathrm{m}^{3}$

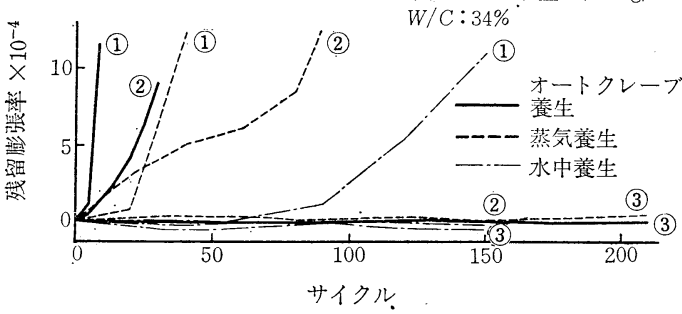

図一8＼cjkstart高強度コンクリートの耐凍害性

であるが，高強度コンクリートの場合は $0.3 \%$ 程度と
さらにこれらを基盤として，他の材料との組合せにより 新たなコンクリートの高性能化も十分期待できるものと 考える。

\section{5. 流動化コンクリート}

流動化コンクリートとは，あらかじめ練りまぜられた コンクリート（ベースコンクリート）に流動化剤を添加 し，これを擋拌して流動性を増大させたコンクリートを いう。その製造方法としては，図一9に示すような方 法が考えられるが，現在のところもっとも多いのは現場 添加方式である。

流動化コンクリートの使用目的は，建築においては軟 練りコンクリートの品質改善であり，乾燥収縮やひびわ れの低減，ブリージングや材料分離の減少，水密性・気 密性の改善，耐久性の向上，水和熱低減などの効果があ げられる。一方, 硬練りコンクリートを従来より使用し てきた土木においては，施工性の改善があげられる。も ちろん, 単位水量や単位セメント量の減少により建築と 同様の効果を期待することもある。

これらの流動化コンクリートは，建築においては倉 庫，サイロ，下水処理場，原子力発電所などといった特 殊な性能が要求されるコンクリートに用いる場 合が多 く, また, 公共建物, 病院, 銀行, 高層建築などにも比 較的よく使用されている。土木においては，鉄道橋，道 路橋, タンク設備, 舗装, ダムなどに使用されている。 なお，流動化コンクリートと高強度コンクリートを併せ た使用方法も，地下連続壁などにその適用が検討されて いる ${ }^{20)}$ 。

流動化によるスランプ 増大量は，5〜8 cm を標準と し，10 cm 以下とするのがよい。我が国の施工例におけ

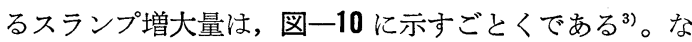
お, 土木においては, 流動化コンクリートのスランプを なる。

高強度コンクリートの乾燥収縮やクリー プは，圧縮強度の小さいコンクリートの 7 割程度であり，さらにオートクレーブ養生 を行った場合には 2〜3 割程度となる。

なお, 高強度コンクリートの凍結融解に 対する抵抗性は，図一8 に示すごとく養生 方法の影響が大きく，オートクレーブ養生 した場合には高強度でも凍結融解に対する 抵抗は低く, $400 \mu \mathrm{m}$ 程度の気泡間隔係数 とすることが必要となっている19)。なお， 通常の水中養生のものでは十分な耐久性を 示すと考えることができる。

高性能減水剤はコンクリートの高強度化 にはなくてはならないものとなっており，

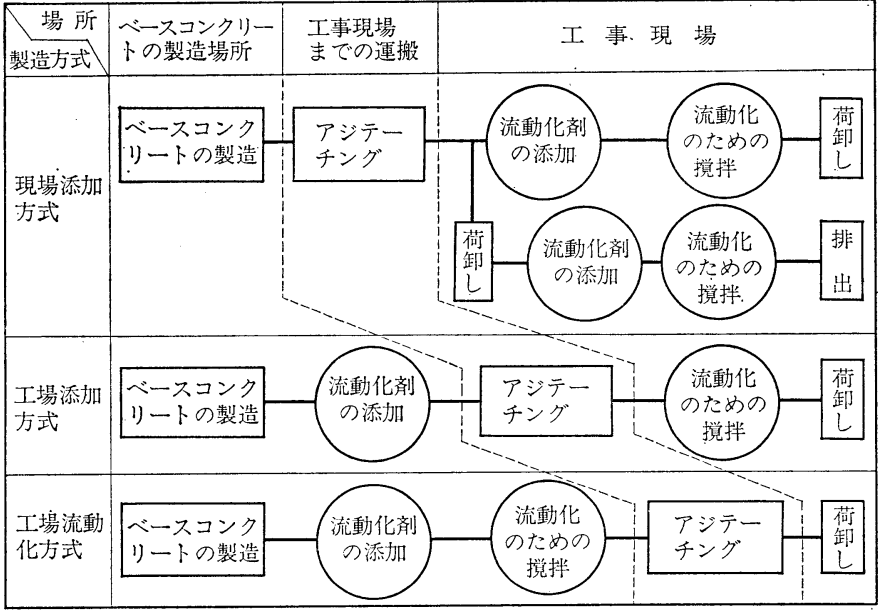

図一9 流動化コンクリートの製造方法 


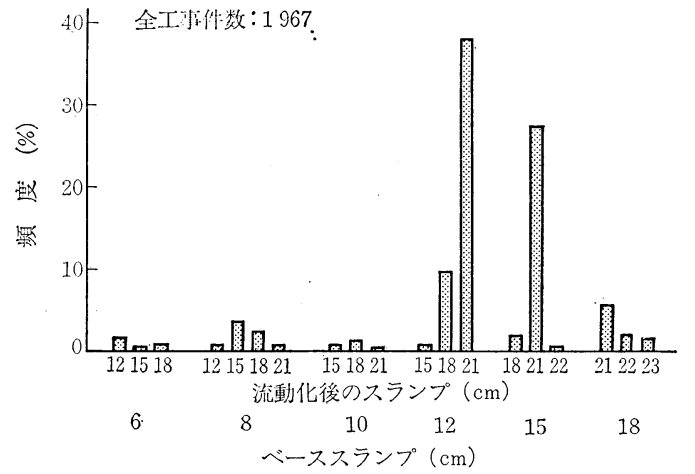

図一10 流動化コンクリートの実績

原則として $18 \mathrm{~cm}$ 以下でこれを定め, 構造物の種類に よるスランプの標準範囲を示している。

流動化コンクリートは, 流動化剛の品質規準が規格化 されていることより, ベーストコンクリートとほぼ同等 の性質を示す必要がある（表一1）。コンクリートの製 造, 性質を含めて, 通常のコンクリートと異なる点, す なわち注意すべき事項は以下のごとくである。

配 (調) 合設計に㧍いては, 細骨材率の選定, 微粉量 に留意する。また，流動化㓮の計量，添加および擋拌と いう作業が追加される。一般に, この作業は工事現場で 行われる場合が多く, トラックアジテータで高速擋拌す る際に発生する騒音は, 現場の立地条件によって規制さ れる場合があるので，十分これらのことを考慮して計画 を立てる必要がある。また, 流動化コンクリートは現 在, その改良方法が検討されているものの，一般にスラ ンプの経時変化が通常のコンクリートに比べて大きい。 従って, これらの点を考慮した施工計画, 施工体制をつ くる必要がある。

コンクリートの耐久性等が問題視されている今日，コ ンクリートの品質を改善する流動化コンクリートの利用 を,さらに拡大して行く必要がある。しかし，現場にお ける流動化剂の投入・擋拌, スランプロス, JIS A 5308 に関連する事項など，まだ解決すべき多くの問題を抱え ている。これらの問題を解決すべくプラントのミキサで 流動化させる，いわゆる流動コンクリートの実用化の検 討もなされている。まだ新しい施工技術である流動化コ ンクリートをより健全に発達させるためには, これらの 問題を一つずつ解決してゆく必要があるら。

\section{6.おわりに}

高性能減水剂と流動化剤について, その概略を説明し た。本稿においてすべての点を網羅できている訳ではな いが，幸い指針には資料集も付いており，本誌でも過去 数回の特集 ${ }^{18), 211,22)}$ が組まれているので参考にしていた だきたい。これら混和剤を用いたからといって, 現在,
巷間で問題にされているコンクリートの耐久性がらみの 問題がすべて解決される訳ではないが，少なくとも健全 なコンクリートを得るための一助とはなり得るものと考 えており，より広範な正しい利用法の拡大を期待するも のである。また，さらに，これらを基礎とした新しい技 術の進歩も期待されよう。

\section{参考 文 献}

1）士木学会 : 高強度コンクリート設計施工指針 (案), コ ンクリートライブラリー，第 47 号, 1980

2）日本建築学会 : 流動化コンクリート施工指針案同解説, 1983

3）土木学会 : 流動化コンクリート施工指針 (案), コンク リートライブラリー，第 51 号, 1983

4) ACI Committee 212 : Admixtures for Concrete, Concrete Int'l, Vol. 33, p. 35, 1981.5

5) Joint Working Party of the Cement Admixtures Association and the Cement and Concrete Association : Superplasticizing admixtures in concrete, C.C. A., 1976

6）近藤・大門・坂井・山中：セメントの流動特性 および 水 和反忘におよぼす高分子の影響, セメント技術年報, Vol. 31 , p. 56,1977

7）立花・目黒・北原・森本・渡辺・古沢・妹尾：コロイド 化学一その新しい展開, p. 121, 共立出版, 1981

8）古沢：サスペンション一その基礎と応用, 表面, Vol. 15, p. 359,1977

9）真鍋・川田：初期水和時のセメントペーストに対するリ グニンスルホン酸 カルシウム系分散剤の作用について, セメント技術年報，Vol. 13, p. 206, 1959

10）服部・山川・今村・鈴江・江尻：流動コンクリートにつ いて，セメント技術年報，Vol. 30, p. 254, 1976

11) E. Sakai, K. Raina, K. Asaga, S. Goto and R. Kondo: Influence of sodium aromatic sulfonates on the hydration of tricalcium aluminate with or without gypsum, Cement \& Concrete Res., Vol. 10, p. 311, 1980

12）小須田・鈴木 : 高強度コンクリートへの 応用例一橋りょ う, コンクリート工学, Vol. 18, No. 7, p. 25, 1980.7

13）長滝・河野・杉山：フレッシュモルタルの粘性構造につ いての考察，セメント技術年報，Vol. 33，p. 101，1979

14) K. Asaga and D.M. Roy : Rheological properties of cement mixes, Cement \& Concrete Res., Vol. 10, p. 287, 1980

15) S. Nagataki, T. Okumura and K. Kodama : Application of high-strength prepacked concrete to offshore structure, Int'l Symp. Offshore Structure, RILEMFIP-CEB, 3.119, 1979

16）安藤：超緻密セメントの建築への利用，建築技術，Vol. $17,1985.8$

17）西・大塩・福沢：オートクレーブ養生した高強度コンク リートパイル，セメント・コンクリート，No. 299, 1972

18）日本コンクリート工学協会：コンクリート用混和剤をめ ぐる最近の動向, 1982

19）長滝・坂井・中村・金：オートクレーブ養生した高強度 コンクリートの耐凍結融解性, 第 4 回コンクリート工学 年次講演会論文集, p. 45,1982

20）北後・佐藤・荻野：流動化コンクリートの地下連続壁へ の適用, 第 38 回土木学会年次学術講演会講 演 要 旨 集, p. 523,1983

21）特集: コンクリートの強度への挑戦, コンクリート工学, Vol. 14, No. 3, 1976.3

22）特集：高性能減水剤の応用, コンクリート工学, Vol. 18, No. $7,1980.7$ 